\title{
PKM Kelurahan Kolongan Satu Kecamatan Tomohon Tengah Tentang Tumbuhan Repelan Nyamuk Penyebab Penyakit Demam Berdarah Dengue
}

\author{
Henny Lieke Rampe ${ }^{1 *}$, Stella Deiby Umboh ${ }^{1}$ dan Meytij Jeane Rampe ${ }^{2}$ \\ ${ }^{1}$ Jurusan Biologi, Fakultas Matematika Dan Ilmu Pengetahuan Alam Universitas Sam Ratulangi \\ ${ }^{2}$ Jurusan Kimia, Fakultas Matematika dan Ilmu Pengetahuan Alam Universitas Negeri Manado \\ *Penulis Korespondensi, Henny L. Rampe Jurusan Biologi FMIPA Universitas Sam Ratulangi Manado 95115. \\ Email: hennyrampe@unsrat.ac.id
}

\begin{abstract}
ABSTRAK
Penyakit Demam Berdarah Dengue (DBD) merupakan penyakit endemis yang banyak ditemui di Indonesia. Penyakit ini disebabkan oleh gigitan nyamuk Aedes aegypti dengan membawa virus dengue pada tiap gigitan. Penyakit DBD merupakan salah satu masalah kesehatan bagi masyarakat yang cenderung meningkat jumlah penderitanya dan semakin luas daerah penyebarannya, sejalan dengan meningkatnya mobilitas dan kepadatan penduduk. Tujuan dan target khusus yang dicapai dalam kegiatan ini adalah : 1) Masyarakat memperoleh pengetahuan tentang dampak negatif penggunaan obat anti nyamuk bagi konsumen dan lingkungan, 2) Memperoleh informasi ilmiah tentang jenis tumbuhan berpotensi repelan nyamuk penyebab penyakit DBD, dan 3)Memberikan informasi ilmiah tentang cara mengusir nyamuk penyebab penyakit DBD dengan bahan alami. Kegiatan dilaksanakan di Kelurahan Kolongan Satu Kecamatan Tomohon Tengah Kota Tomohon Sulawesi Utara. Hasil kegiatan penyuluhan berdasarkan hasil post test, terjadi peningkatan pengetahuan masyarakat yang ditandai dengan jawaban benar oleh peserta. Prosentase peningkatan pengetahuan untuk topik : 1) Penyebab penyakit DBD sebesar $26.67 \%$, 2) Organisme yang menularkan penyakit DBD sebesar 50.00\%, 3) Nyamuk penyebab penyakit DBD sebesar 33.33\%, 4) Dampak negatif repelan kimia sebesar 43.33\%, 5) Tindakan mencegah penyebaran nyamuk penyebab penyakit DBD sebesar $33.33 \%$,6) Tempat potensial berkembangnya nyamuk penyebab penyakit DBD sebesar $33.33 \%$ dan 7)Tumbuhan repelan dengan kisaran 33.33 $53.33 \%$.
\end{abstract}

Kata kunci : Tumbuhan Repelan Nyamuk, Demam Berdarah Dengue

\begin{abstract}
Dengue Hemorrhagic Fever (DHF) is an endemic disease that is commonly found in Indonesia. This disease is caused by the bite of Aedes aegypti mosquito which carrying the dengue virus. DHF is one of the health problems for society that tend to increase the number of patients and wider the distribution area, in line with the increase of mobility and population density.The objectives and targets to be achieved from this activity are: 1) Communities gain knowledge about the negative impacts of using antimosquito drugs for consumers and the environment, 2) Obtain the scientific information about plant species which have the potential to repel mosquitoes that cause dengue disease, and 3) Provide the scientific information about how to repel mosquitoes that cause dengue disease with natural ingredients. The activity was carried out in Kolongan Satu Village, Tomohon Tengah District, Tomohon City, North Sulawesi. From the post test conducted after the counseling activities, it was found that there was an increase in community knowledge, which was marked by the correct answers from the participants. Percentage of increased knowledge for the topic: 1) As much as $26.67 \%$ is related to increasing the knowledge about the causes of DHF; 2) As much as $50.00 \%$ is related to increasing the knowledge about organisms that transmit DHF; 3) Then $33.33 \%$, related to increasing the knowledge about mosquitoes that cause dengue disease; 4) Then 43.33\%, related to knowledge about negative effects of chemical repairs; 5) As much as 33.33\%, related to knowledge about measures to prevent the spread of mosquitoes that cause DHF; 6) Then 33.33\%, related to increasing the knowledge about potential places for
\end{abstract}


mosquitoes growth that cause DHF; and 7) And about 33.33-53.33\%, related to increasing the knowledge about the repellent plants.

Keywords: Mosquito Repellent Plants, Dengue Hemorrhagic Fever

\section{PENDAHULUAN}

\section{Analisis Situasi}

Indonesia merupakan negara tropis dengan mengalami dua musim yaitu musim hujan dan musim kemarau. Perubahan musim dapat menyebabkan berkembangnya nyamuk sebagai vektor dari penyakit seperti malaria, demam berdarah dengue (DBD), Japanese Encepalatis (demam chikungunya), dan vilariasis (Dahniar, 2011). Kota Tomohon berada di wilayah pegunungan yang terletak antara $01^{\circ} 18^{\prime} 51^{\prime \prime}$ Lintang Utara dan 124'49'40" Bujur Timur, memiliki luas 147,21 km2 dan berada pada ketinggian 400-1500 meter dpl dengan kisaran suhu $18^{\circ} \mathrm{C}-30^{\circ} \mathrm{C}$. Dengan kecepatan angin rata-rata $3,35 \mathrm{knot} / \mathrm{bulan}$, kelembapaan udara rata-rata 90,67 \%/bulan, temperatur udara $22,33{ }^{\circ} \mathrm{C} /$ bulan, curah hujan rata-rata $291,04 \mathrm{~mm} /$ bulan dan tekanan udara 940,10 (BPS, 2017).

Di Propinsi Sulawesi Utara kasus DBD pada bulan Januari Tahun 2019 terus meningkat, yaitu lebih dari 67 warga menderita $\mathrm{DBD}, 3$ orang diantaranya meninggal dunia (Anonim, 2019a). Selanjutnya untuk Kota Tomohon jumlah kasus DBD sepanjang tahun 2018 ada 116 kasus, dua diantaranya meninggal dunia. Angka ini naik drastis, hingga 200 prosen. Tahun 2017, jumlah kasus DBD hanya 20 kasus, satu orang meninggal dunia (Anonim, 2019b).

Penyakit DBD merupakan penyakit endemis yang banyak ditemui di Indonesia. Penyakit ini disebabkan oleh gigitan nyamuk Aedes aegypti dengan membawa virus dengue pada tiap gigitan. Penyakit DBD merupakan salah satu masalah kesehatan bagi masyarakat yang cenderung meningkat jumlah penderitanya dan semakin luas daerah penyebarannya, sejalan dengan meningkatnya mobilitas dan kepadatan penduduk (Depkes RI, 1995).
Beberapa faktor yang berisiko terjadinya penularan dan semakin berkembangnya penyakit DBD adalah pertumbuhan jumlah penduduk yang tidak memiliki pola, faktor urbanisasi yang tidak berencana dan terkontrol, semakin majunya sistem transportasi sehingga mobilisasi penduduk sangat mudah, sistem pengelolaan limbah dan penyediaan air bersih yang tidak memadai, berkembangnya penyebaran dan kepadatan nyamuk, kurangnya system pengendalian nyamuk yang efektif, serta melemahnya struktur kesehatan masyarakat.

Selain faktor lingkungan tersebut status imunologi seseorang, serotipe virus yang menginfeksi, usia dan riwayat genetik juga berpengaruh terhadap penularan penyakit. Perubahan iklim dunia sehingga memicu kenaikan suhu udara, perubahan pola musim hujan dan kemarau juga diperkirakan sebagai penyebab peningkatan risiko penularan DBD dan peningkatan risiko terkait kemunculannya (Kemenkes RI., 2015).

Peningkatan jumlah kejadian DBD diduga kuat berhubungan dengan faktor perilaku masyarakat dalam melakukan tindakan pemberantasan sarang nyamuk (PSN) yang masih buruk. Hal ini dapat terlihat dengan angka bebas jentik di Indonesia hingga tahun 2015 sebesar $52,54 \%$ yang jauh dari target pemerintah yaitu $\geq 95 \%$. Kondisi ini diperburuk dengan fakta bahwa belum ada obat dan vaksin yang dinilai efektif untuk penyakit DBD, sehingga perilaku PSN dinilai penting dilakukan untuk mencegah penularan DBD (Kemenkes RI., 2015). Kondisi saat ini pencegahan penyakit demam berdarah dilakukan mulai dari Pemberantasan sarang Nyamuk (PSN), fogging, penggunaan larvasida/ pemberantasan jentik nyamuk (larvasidasi), dan penggunaan obat nyamuk (termasuk insektisida). 
VIVABIO

Jurnal Pengabdian Multidisiplin

Berbagai usaha dilakukan masyarakat untuk membunuh atau menghindari gigitan nyamuk, salah satunya dengan penggunaan obat anti nyamuk baik dalam bentuk semprot, lotion, bakar, atau bentuk lainnya. Penggunaan obat anti nyamuk dapat memberikan dampak negatif terhadap konsumen dan lingkungan, karena komponen bahan kimia dalam produk tersebut.

Insektisida merupakan kelompok pestisida yang terbesar dan terdiri atas beberapa jenis bahan kimia yang berbeda, antara lain organoklorin, organofosfat, kabamat, piretroid, dan DEET. Penggunaan organoklorin telah dilarang di dunia dan Indonesia (Kusumastuti, 2014, ). Misalnya golongan bahan kimia berbahaya yang sering digunakan dalam obat anti nyamuk adalah golongan karbamat seperti propoxur, piretroid seperti permethrin, organofosfat seperti Dichlorovinyl Dimethyl Phospate (DDVP), dan diethylmetatoluamide (DEET), dan golongan organoklorin (Fei and Xin, 2007; Faulde et. al., 2012 ; Murlidhar, et. al., 2015; Raja, et. al., 2015 dan Rahmatullah, 2018).

Penggunaan obat anti nyamuk kimia ini dapat memberikan dampak negatif bagi pengguna dan lingkungan, karena residu obat nyamuk kimia dapat mencemari lingkungan, dan mengakibatkan resistensi. Residu yang tertinggal dapat menyebabkan masalah kesehatan seperti iritan terhadap kulit, bahkan jika terserap dalam dosis tinggi dapat menyebabkan kekejangan otot. Selain itu jika terhirup dan masuk ke saluran pernapasan, dalam waktu lama dapat mengakibatkan perubahan dan kerusakan jaringan penyusun saluran napas yang nantinya dapat mengganggu sistem pernapasan (Dahniar, 2011).

Saat ini masyarakat lebih banyak menggunakan obat anti nyamuk bentuk semprot, lotion atau bakar untuk menanggulangi nyamuk. Perilaku masyarakat cenderung mengarah ke sifat instan, artinya mudah diperoleh dan digunakan, namun tanpa disadari pengunaan obat anti nyamuk kimia dapat memberikan dampak negative bagi kesehatan konsumen. Salah satu cara mengurangi pemakaian obat anti nyamuk yaitu dengan menggunakan tumbuhan yang berpotensi repelan atau pengusir nyamuk. Tanaman Lavender (Lavandula angustifolia), kemangi (Ocimum basilicum), Sambiloto (Andrographis paniculata), salam (Syzygium polyanthum), zodiac Evodia suaveolens), geranium (Pelargonium citrosa), jeruk nipis (Citrus aurantifolia) Sere (Cymbopogon citratus), patikan kerbau (Euphorbia hirta), kayu manis (Cinnamomum verum), lengkuas (Alpinia galanga), babadotan (Ageratum conyzoides), alpukat (Persea americana) dan marygold (Tagetes erecta) diketahui berpotensi repelan nyamuk (Panneerselvam, et.al., 2013, Mendki, et al., 2015; Aseptianova et.al., 2017 dan Millati, et. al., 2018).

Tanaman tersebut sudah menunjukkan efikasi yang baik melawan beberapa spesies nyamuk Aedes aegypti Penelitian tumbuhan berpotensi repelan nyamuk telah dilakukan oleh peneliti antara lain tanaman jeruk nipis (Saleh, et.al., 2014), emulgel minyak atsiri biji pala Ikhsanudin dan Azizah (2017), minyak atsiri daun kemangi (Fajarini dan Murrukmihadi, 2015), efektifitas daun mint, lengkuas, sambioloto, babadotan, daun alpokat, daun salam, pucuk merah dan daun zodiac (Aseptianova et. al., 2017).

Tumbuhan repelan nyamuk diketahui mengandung senyawa metabolit sekunder seperti flavonoid, saponin, tanin, alkaloid dan terpenoid (Meda, 2005, Liem et al., 2013, Harahap, 2014). Flavonoid berperan sebagai proteksi biotik (herbívora dan patogen) dan cekaman abiotik (radiasi UV), bersifat antioksidatif dan mempertahan redox dalam sel (Mierziak et al., 2014). Triterpenoid lain, limnoid pada buah jeruk bertindak sebagai antiherbivor dan bersifat toksik (Mazid et al., 2011). Alkaloid steroid misalnya solanin, bersifat racun dikenal sebagai glikoalkaloid pada tumbuhan Solanaceae. Solanin bersifat fungisida dan pestisida, dan merupakan salah satu 
VIVABIO

Jurnal Pengabdian Multidisiplin

resistensi alami tumbuhan (Sarker dan Nahar, 2007).

Hasil survey lapang, di Kelurahan Kolongan Satu Kecamatan Tomohon Tengah Kota Tomohon sangat berpotensi dilakukan penanaman tumbuhan repelan nyamuk. Tumbuhan patikan kerbau dan babadotan tumbuh liar di perkebunan masyarakat, tumbuhan sambiloto, sere, kayu manis, lengkuas, alpukat dan salam banyak dibudidayakan di perkebunan. Selanjutnya tanaman zodiac, geranium dan lavender populasi sangat terbatas sebagai tanaman hias. Hasil konsultasi masyarakat Kolongan Satu, diperoleh informasi bahwa pengetahuan masyarakat tentang tanaman repelan sangat rendah, karena belum pernah dilakukan penyuluhan tentang tanaman berpotensi repelan nyamuk. Maka dengan dilakukannya kegiatan ini diharapkan memberi pengetahuan, ketrampilan masyarakat tentang perilaku hidup bersih, sehat serta potensi tumbuhan repelan nyamuk penyebab penyakit DBB.

\section{Permasalahan mitra}

Mengacu dari Rencana Strategis (RENSTRA) Dinas Kesehatan Daerah Propinsi Sulawesi Utara Tahun 2016 - 2021 bahwa Pembangunan kesehatan dilaksanakan melalui peningkatan: 1) Upaya kesehatan,2) Pembiayaan kesehatan, 3) Sumber daya manusia kesehatan, 4) Sediaan farmasi, alat kesehatan, dan makanan, 5) Manajemen dan informasi kesehatan, dan 6) Pemberdayaan masyarakat. Upaya tersebut dilakukan dengan memperhatikan dinamika kependudukan, epidemiologi penyakit, perubahan ekologi dan lingkungan, kemajuan Ilmu Pengetahuan dan Teknologi (IPTEK), serta globalisasi dan demokratisasi dengan semangat kemitraan dan kerjasama lintas sektoral. Penekanan diberikan pada peningkatan perilaku dan kemandirian masyarakat serta upaya promotif dan preventif.

Menitik beratkan pada peningkatan perilaku dan kemandirian masyarakat serta upaya promotif dan preventif di Kota Tomohon, maka ketercapaian program masih belum maksimal tercermin dari masih meningkatnya kasus penyakit DBD. Perilaku masyarakat yang masih rendah dalam hal upaya pengendalian vektor DBD secara mandiri. Program Pemberantasan Sarang Nyamuk dengan Menutup, Menguras dan Mendaur Ulang Plus (PSN 3M Plus ), tentang perilaku menghilangkan sarang nyamuk vektor DBD dan langkah untuk mengurangi kontak atau gigitan nyamuk Aedes.

Saat ini masyarakat cenderung menggunakan obat anti nyamuk kimia dalam bentuk oles, semprot atau bakar dlam mengusir atau membunuh nyamuk, yang berdampak negative bagi kesehatan seperti bahan ini dapat menimbulkan efek toksik, termasuk ensefalopati pada anak anak, sindrom urtikaria, anafilaksis, hipotensi dan penurunan denyut jantung. Penggunaan tanaman pengusir nyamuk (repellent) merupakn alternative terbaik dalam menekan populasi nyamuk penyebab penyakit DBD.

Survei yang dilakukan di rumah di Kelurahan Kolongan Satu, pemanfaatan pekarangan rumah untuk menanam tanaman pengusir nyamuk masih sangat rendah. Hal ini disebabkan kurangnya pengetahuan masyarakat akan jenis tumbuhan yang berpotensi repelan nyamuk.

Melalui kegiatan ini permasalahan yang akan ditangani adalah :

1. Memberikan informasi ilmiah tentang jenisjenis tumbuhan yang berpotensi repelan nyamuk penyebab penyakit Demam Berdarah Dengue

2. Memberikan informasi ilmiah cara mengusir nyamuk penyebab penyakit Demam Berdarah Dengue dengan bahan alami.

3. Melakukan kegiatan penanaman tumbuhan berpotensi repelan nyamuk penyebab penyakit Demam Berdarah Dengue

\section{Tujuan dan Manfaat Kegiatan}

Melalui kegiatan ini target luaran yang akan dicapai adalah : 
1. Masyarakat memperoleh pengetahuan tentang dampak negatif penggunaan obat anti nyamuk bagi konsumen dan lingkungan

2. Memperoleh informasi ilmiah tentang jenis tumbuhan berpotensi repelan nyamuk penyebab penyakit DBD.

3. Memberikan informasi ilmiah tentang cara mengusir nyamuk penyebab penyakit DBD dengan bahan alami.

\section{METODE PELAKSANAAN}

Strategi yang ditawarkan untuk mengurangi penggunaan obat anti nyamuk yang memberikan dampak negatif bagi konsumen dan lingkungan, dan kurangnya pengetahuan masyarakat tentang jenis tumbuhan yang berpotensi repelan nyamuk penyebab penyakit DBD, maka dilakukan kegiatan penyuluhan dan praktek budidaya tanaman repelan nyamuk melalui kegiatan :

1. Pemberian teori/ceramah, meliputi :

a. Tinjauan umum tentang DBD

b. Dampak negatif penggunaan obat anti nyamuk kimia bagi konsumen dan lingkungan

c. Cara cara mengusir nyamuk penyebab penyakit DBD dengan bahan alami

d. Tumbuh-tumbuhan yang berpotensi repelan nyamuk DBD seperti :Sambiloto (Andrographis paniculata), Sere (Cymbopogon citratus), Lavender (Lavandula angustifolia), kemangi (Ocimum basilicum), patikan kerbau (Euphorbia hirta), kayu manis (Cinnamomum verum), umbi lengkuas (Alpinia galanga), babadotan (Ageratum conyzoides), daun alpukat (Persea americana) daun salam (Syzygium polyanthum), dan daun zodiac Evodia suaveolens), geranium (Pelargonium citrosa), marygold (Tagetes erecta).

\section{Evaluasi dan monitoring}

Pada tahap ini akan dievaluasi sekaligus monitoring capaian dan keberlanjutan ketrampilan yang ditawarkan, mengenai hambatan dan kemungkinan solusi yang dapat dikembangkan untuk mencapai sasaran yang ditergetkan.

\section{HASIL DAN LUARAN YANG DICAPAI}

Kegiatan Program Kemitraan Masyarakat (PKM) tentang tumbuhan repelan nyamuk penyebab penyakit demam berdarah dengue, diawali dengan kegiatan Pre-test, pemberian teori dengan metode ceramah, diskusi / sharing pengetahuan, selanjutnya kegiatan evaluasi dan monitoring.

Kegiatan pre-test dimaksudkan untuk mengukur pengetahuan awal peserta penyuluhan tentang tumbuhan repelan nyamuk penyebab penyakit DBD. Kegiatan pre-test dilaksanakan 15 menit sebelum pemberian materi, dimana peserta diberi pertanyaan dalam bentuk pilihan ganda dan memilih satu jawaban yang paling tepat. Sejumlah 10 pertanyaan diberikan kepada 30 peserta yang dipilih secara acak. Hasil evaluasi kemampuan awal peserta pada setiap nomor soal melalui penilaian pre-test disajikan pada Tabel 1.

Berdasarkan Tabel 1 dan Gambar 1, Sebanyak 20 peserta yang menjawab benar pada nomor soal 3,5 dan 6. Sebanyak 15 orang menjawab benar pada nomor soal 4 , sebanyak 14 orang menjawab benar pada nomor soal 1,7 dan 9 , sebanyak 13 orang menjawab benar pada nomor soal 2 dan 10 , dan sebanyak 12 orang menjawab benar pada nomor soal 8 .

Tabel 1. Hasil Pre-Test Peserta Penyuluhan Pada Setiap Nomor Soal

\begin{tabular}{clcc}
\hline \multirow{2}{*}{ No } & \multicolumn{1}{c}{ Materi } & \multicolumn{2}{c}{ Jumlah (orang) } \\
\cline { 3 - 4 } & & $\begin{array}{c}\text { Jawaba } \\
\text { n benar }\end{array}$ & $\begin{array}{c}\text { Jawaban } \\
\text { salah }\end{array}$ \\
\hline 1 & $\begin{array}{l}\text { Penyebab penyakit DBD } \\
2\end{array}$ & 14 & 16 \\
& $\begin{array}{l}\text { Organisme yang } \\
\text { menularkan penyakit }\end{array}$ & 13 & 17 \\
& $\begin{array}{l}\text { DBD } \\
3\end{array}$ & 20 & 10 \\
& $\begin{array}{l}\text { Nyamuk penyebab } \\
\text { penyakit DBD }\end{array}$ & 15 & 15 \\
4 & $\begin{array}{l}\text { Dampak negatif repelan } \\
\text { kimia }\end{array}$ & 15 & \\
5 & Tindakan mencegah & 20 & 10 \\
\hline
\end{tabular}


VIVABIO

Jurnal Pengabdian Multidisiplin

\begin{tabular}{|c|c|c|c|}
\hline & $\begin{array}{l}\text { penyebaran nyamuk } \\
\text { penyebab penyakit DBD }\end{array}$ & & \\
\hline 6 & $\begin{array}{l}\text { Tempat potensial } \\
\text { berkembangnya nyamuk } \\
\text { penyebab penyakit DBD }\end{array}$ & 20 & 10 \\
\hline 7 & Tumbuhan repelan & 14 & 16 \\
\hline 8 & Tumbuhan repelan & 12 & 18 \\
\hline 9 & Tumbuhan repelan & 14 & 16 \\
\hline 10 & Tumbuhan repelan & 13 & 17 \\
\hline
\end{tabular}

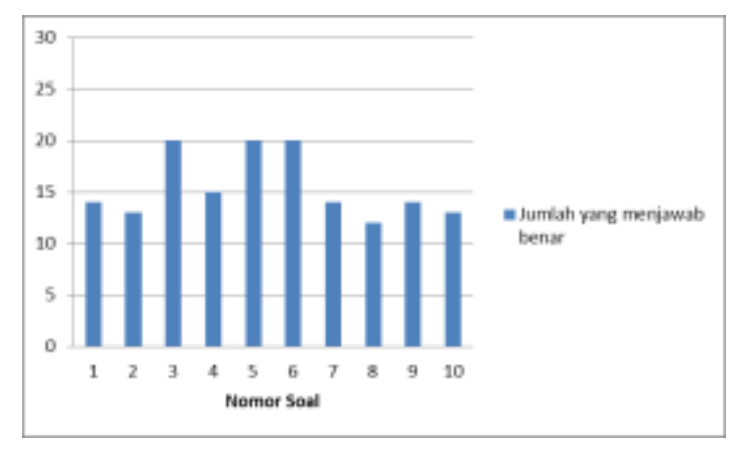

Gambar 1. Hasil Pre-Test Peserta

Penyuluhan Pada Setiap Nomor Soal

Kegiatan post-test dilaksanakan selama 15 menit setelah akhir ceramah / penyampaian materi, diskusi dan sharing pengalaman peserta penyuluhan. Sebanyak 10 soal, diberikan pada 30 orang peserta dengan soal yang sama untuk pre-test. Kegiatan post-test dimaksudkan untuk mengukur kemampuan daya serap dan pengetahuan peserta penyuluhan setelah mengikuti penyajian materi. Data hasil post-test berdasarkan jawaban dari setiap nomor soal ditunjukkan pada Tabel 2 dan Gambar 2.

Tabel 2. Hasil Post-Test Peserta Penyuluhan Pada Setiap Nomor Soal

\begin{tabular}{|c|c|c|c|}
\hline \multirow[b]{2}{*}{ No } & \multirow[b]{2}{*}{ Materi } & \multicolumn{2}{|c|}{ Jumlah (orang) } \\
\hline & & $\begin{array}{c}\text { Jawaban } \\
\text { benar }\end{array}$ & $\begin{array}{c}\text { Jawaban } \\
\text { salah }\end{array}$ \\
\hline 1 & $\begin{array}{l}\text { Penyebab penyakit } \\
\text { DBD }\end{array}$ & 26 & 4 \\
\hline 2 & $\begin{array}{l}\text { Organisme yang } \\
\text { menularkan penyakit } \\
\text { DBD }\end{array}$ & 28 & 2 \\
\hline 3 & $\begin{array}{l}\text { Nyamuk penyebab } \\
\text { penyakit DBD }\end{array}$ & 30 & 0 \\
\hline
\end{tabular}

\begin{tabular}{clcl}
\hline 4 & $\begin{array}{l}\text { Dampak negatif } \\
\text { repelan kimia } \\
5\end{array}$ & 28 & 2 \\
& $\begin{array}{l}\text { Tindakan mencegah } \\
\text { penyebaran nyamuk } \\
\text { penyebab penyakit }\end{array}$ & 30 & 0 \\
$\quad$ DBD & & \\
$6 \quad$ Tempat potensial & 30 & 0 \\
& berkembangnya \\
nyamuk penyebab & & \\
7 & penyakit DBD & & \\
8 & Tumbuhan repelan & 27 & 3 \\
9 & Tumbuhan repelan & 28 & 2 \\
10 & Tumbuhan repelan & 24 & 6 \\
\hline
\end{tabular}

Berdasarkan data Tabel 2, terlihat disini terjadi peningkatan pengetahuan tentang tumbuhan repelan nyamuk penyebab penyakit DBD. Sebanyak 30 orang menjawab benar pada nomor soal 3,5 dan 6 . Sebanyak 28 orang menjawab benar pada soal nomor 2,4 dan 8 . Sebanyak 27 orang menjawab benar pada soal nomor 7 , sebanyak 26 orang menjawab benar pada soal nomor 1 , sebanyak 24 orang menjawab benar pada soal nomor 9 dan 10 .

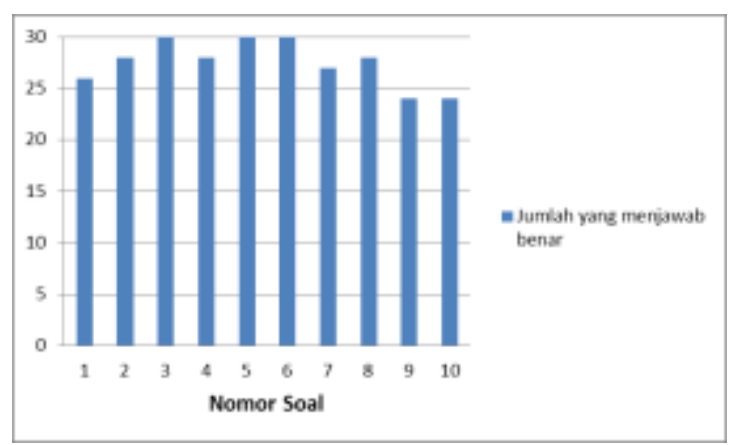

Gambar 2. Hasil Post-Test Peserta

Penyuluhan Pada Setiap Nomor Soal

Kegiatan penyuluhan, sharing pengetahuan dan penyerahan bibit tumbuhan repelan nyamuk ditunjukkan pada Gambar 3. 
VIVABIO

Jurnal Pengabdian Multidisiplin
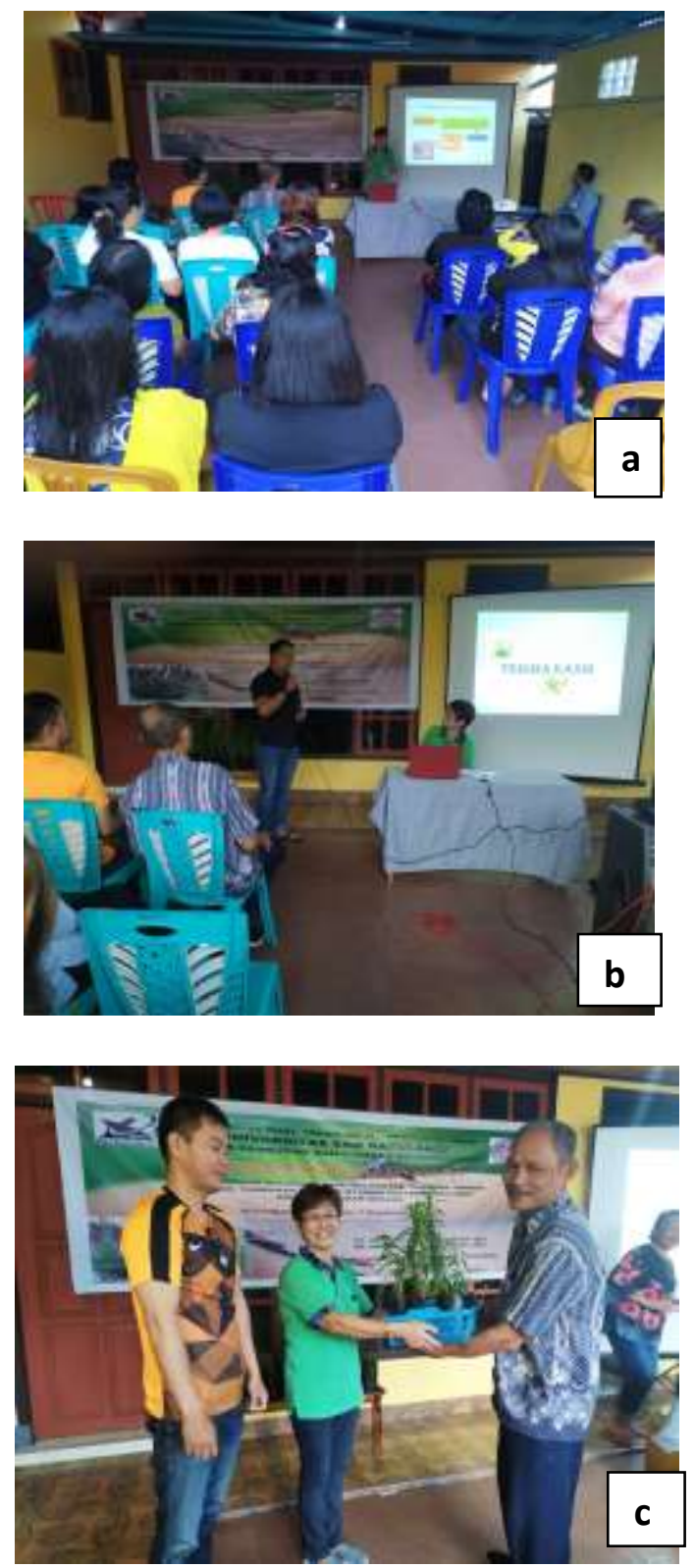

Gambar 3. Pemberian Materi pada Peserta (a).

Sharing Pengetahuan oleh Peserta (b), Penyerahan Bibit Tumbuhan Repelan Nyamuk (c).

Perbedaan soal yang dijawab benar pada kegiatan pre-test dan post test ditunjukkan pada Gambar 3.

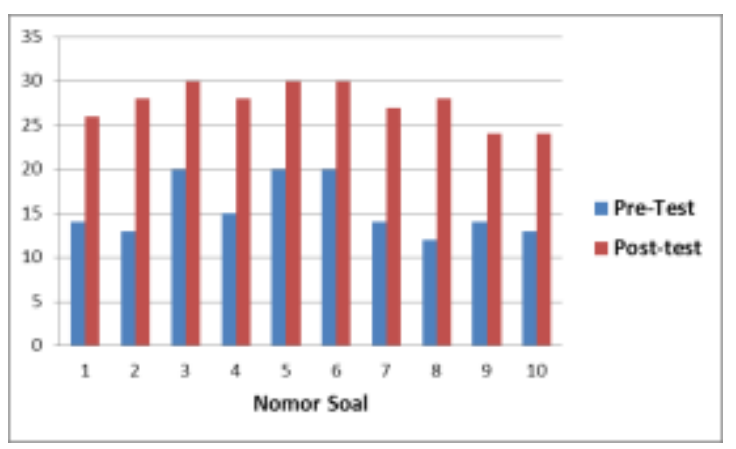

Gambar 3. Perbedaan hasil Pre-test dan Post-test peserta penyuluhan

Pelaksanaan penyuluhan di Lingkungan Satu Kelurahan Kolongan Satu, juga dihadiri oleh peserta dari Lingkungan 7 Kelurahan Kolongan. Peserta dengan berbagai latar belakang pendidikan, profesi dan umur. Masyarakat sekitar juga hadir dan memberikan respon positif berkenaan dengan kegiatan penyuluhan, karena merasa begitu penting dan sangat bermanfaat tentang materi potensi tumbuhan repelan nyamuk penyebab penyakit DBD. Dalam pelaksaan kegiatan penyuluhan para peserta sangat tekun mengikuti penyuluhan yang disampaikan oleh Tim Penyuluh. Berbagai pengetahuan melalui sharing pengalaman disampaikan oleh peserta penyuluhan, sehingga terjadi transfer pengetahuan pada peserta penyuluhan. Prosentase peningkatan capaian hasil test ditunjukan pada Tabel 3 dan Gambar 4.

Berdasarkan data Tabel 3, diperoleh bahwa peningkatan jawaban benar oleh peserta, prosentase tertinggi pada soal nomor 8 yaitu $53.33 \%$, diikuti soal nomor 2 yaitu $50.00 \%$ dan soal nomor 4 dan 7 yaitu $43.33 \%$. Tingginya prosentase kenaikan jawaban benar oleh peserta pada soal nomor 2, disebabkan awalnya konsep tentang penyebab penyakit DBD dan yang menularkan penyebab penyakit DBD masih dianggap sama oleh peserta.

Tabel 3. Prosentase Kenaikan Nilai Hasil Test

Peserta Penyuluhan 
penularan melalui pengendalian nyamuk vektor.

\begin{tabular}{clc} 
No & \multicolumn{1}{c}{ Materi } & $\begin{array}{c}\text { Prosentase } \\
(\%)\end{array}$ \\
\hline 1 & Penyebab penyakit DBD & 26.67 \\
2 & $\begin{array}{l}\text { Organisme yang menularkan } \\
\text { penyakit DBD }\end{array}$ & 50.00 \\
3 & $\begin{array}{l}\text { Nyamuk penyebab penyakit } \\
\text { DBD }\end{array}$ & 33.33 \\
& \\
4 & $\begin{array}{l}\text { Dampak negatif repelan } \\
\text { kimia }\end{array}$ & 43.33 \\
5 & Tindakan mencegah & 33.33 \\
& penyebaran nyamuk & \\
& penyebab penyakit DBD & \\
6 & $\begin{array}{l}\text { Tempat potensial } \\
\text { berkembangnya nyamuk }\end{array}$ & 33.33 \\
& penyebab penyakit DBD & \\
7 & Tumbuhan repelan & 43.33 \\
8 & Tumbuhan repelan & 53.33 \\
9 & Tumbuhan repelan & 33.33 \\
10 & Tumbuhan repelan & 36.67 \\
\hline
\end{tabular}

Pengetahuan tentang virus masih rendah, dan ketika dalam kegiatan penyuluhan direspon balik, pada umumnya peserta hanya mengetahui "Virus", tapi deskripsi virus itu sendiri masih sangat terbatas. Begitu halnya dengan materi nyamuk Aedes segypti, beberapa peserta dapat mendeskripsikan dengan baik, dalam hal organisme kelompok serangga, waktu serangan, siklus hidup dan ekologi.

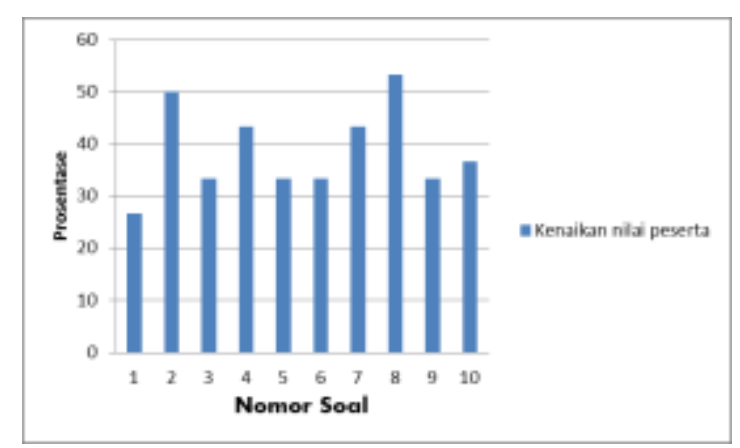

Gambar 4. Prosentase Kenaikan Nilai Hasil Test Peserta Penyuluhan

Penyakit DBD saat ini masih menjadi masalah kesehatan masyarakat, karena di setiap tahun secara siklus terjadi wabah penyakit DBD. Penanggulangan dan pencegahan penyakit DBD lebih banyak difokuskan pada pemutusan rantai
Upaya yang dilakukan untuk pengendalian nyamuk yaitu : 1) pengendalian untuk nyamuk Aedes menggunakan sistem pengasapan, 2) pengabutan dan 3) gerakan $3 \mathrm{M}$ (menutup, menguras dan menimbun).

Penyakit DBD disebarkan oleh nyamuk Aedes aegypti sangat berbahaya, sehingga perlu penanganan yang cepat dan akurat pada penderita DBD. Berdasarkan hasil sharing pengalaman dari peserta penyuluhan, umumnya untuk mengusir nyamuk masyarakat menggunakan obat antinyamuk semprot, bakar, ataupun lotion. Penggunaan obat antinyamuk kimia memberikan dampak negatif karena komponen bahan kimia yang ada didalam produk tersebut. Kebanyakan formula produk anti nyamuk yang beredar di pasaran mengandung DEET (N,N-Diethyl-metatoluamide), Picaridin (2-(2- hydroxyethyl)-1piperidinecarboxylic acid 1-methylpropyl ester), $\mathrm{N}, \mathrm{N}$-diethyl phenylacetamide (DEPA) (Raja et al, 2015; Murlidhar et al., 2015).

Penggunaan obat anti nyamuk kimia ini dapat meninggalkan residu, mencemari lingkungan, dan dapat mengakibatkan resistensi. Residu yang tertinggal dapat menyebabkan masalah kesehatan seperti iritan terhadap kulit, bahkan jika terserap dalam dosis tinggi dapat menyebabkan kekejangan otot. Selain itu jika terhirup dan masuk ke saluran pernapasan, dalam waktu lama dapat mengakibatkan perubahan dan kerusakan jaringan penyusun saluran napas yang nantinya dapat mengganggu sistem pernapasan.

Untuk menghindari efek negatif dari penggunaan anti nyamuk yang berasal dari bahan-bahan kimia, maka melalui penyuluhan ini memberikan informasi potensi tumbuhan repelan nyamuk seperti sambiloto, sere wangi, lavender, kemangi, patikan kerbau, kayu manis, umbi lengkuas, babadotan, daun alpukat, daun salam, dan daun zodiac geranium, marigold, jeruk nipis, Zodia, Kamboja, Selasih dan cengkeh, Kecombrang, bunga krisan, daun mint dan tapak dara dan sambiloto. 
VIVABIO

Jurnal Pengabdian Multidisiplin

Dalam kegiatan penyuluhan dibagikan bibit bunga lavender kepada peserta, sehingga kegiatan ini memberikan peningkatan pengetahuan, perubahan perilaku dan sikap secara nyata kepada peserta. Kegiatan monitoring dilakukan untuk memantau keberlanjutan program dalam hal ini pengembangan tanaman Lavnder dan tanaman repelan nyamuk DBD lainnya.

\section{KESIMPULAN DAN SARAN}

\section{Kesimpulan}

Hasil kegiatan penyuluhan berdasarkan hasil post test, terjadi peningkatan pengetahuan masyarakat yang ditandai dengan jawaban benar oleh peserta. Prosentase peningkatan pengetahuan untuk topik : 1) Penyebab penyakit DBD sebesar $26.67 \%$, 2) Organisme yang menularkan penyakit DBD sebesar $50.00 \%, 3)$ Nyamuk penyebab penyakit DBD sebesar 33.33\%, 4) Dampak negatif repelan kimia sebesar $43.33 \%$, 5) Tindakan mencegah penyebaran nyamuk penyebab penyakit DBD sebesar 33.33\%, 6) Tempat potensial berkembangnya nyamuk penyebab penyakit DBD sebesar $33.33 \%$ dan 7)Tumbuhan repelan dengan kisaran $33.33-53.33 \%$.

\section{Saran}

Berdasarkan hasil kegiatan Program Kemitraan Masyarakat (PKM), maka untuk meminimalisir penggunaan repelan kimia nyamuk penyebab penyakit DBD, maka dapat digunakan tumbuhan yang berpotensi repelan seperti tumbuhan lavender, sambiloto, sere, kemangi, patikan kerbau, kayu manis, umbi lengkuas, babadotan marygold dan jeruk.

\section{UCAPAN TERIMAKASIH}

Terima kasih disampaikan kepada Rektor Universitas Sam Ratulangi Manado dan Ketua Lembaga Penelitian dan Pengabdian Pada Masyarakat UNSRAT, yang telah memberikan bantuan dana melalui Skim PKM sumber dana PNBP Tahun 2019. Terima kasih juga kepada kepala dan wakil kepala Lingkungan Satu,
Kelurahan Kolongan Satu Kecamatan Tomohon Tengah yang menjadi mitra dalam kegiatan PKM ini.

\section{DAFTAR PUSTAKA}

Anonim 2019a. Fakta-Fakta Kasus DBD di Sulut: Jumlah Kematian, Belum KLB hingga Pasien Membludak di RSUP Kandou.

http://manado.tribunnews.com/2019/01/

10/fakta-fakta-kasus-dbd-di-sulutjumlah-kematian-belum-klb-hinggapasien-membludak-di-rsup-kandou.

(Diakses 18 Februari 2019).

Anonim. 2019b. 116 Warga Tomohon Derita DBD, 2 Meninggal. https://manadopostonline.com/read/ 2019/01/08/116-Warga-TomohonDerita-DBD-2-Meninggal/51733. Manado post online. (Diakses 8 Januari 2019)

Anonim. 2019c. Rencana Strategis (Renstra) Dinas Kesehatan Daerah Pripinsi Sulawesi Utara Tahun 2016 2021http://dinkes.sulutprov.go.id/ 2018/03/20/rencana-strategis-renstradinas-kesehatan-daerah-provinsisulawesi-utara-tahun-2016-2021/. Diakses 20 Maret 2018.

Aseptianova, T.F. Wijayanti dan N. Nuraini. 2017. Efektifitas Pemanfaatan Tanaman Sebagai Insektisida Elektrik untuk Mengendalikan Nyamuk Penular DBD. Bioeksperimen 3(2) : 10-19.

BPS 2017. Kota Tomohon.

ppsp.nawasis.info/.../pokja/.../kota.tomo hon/BAB\%20II\%20BPS \%20TOMOHON (Diakses 2 Desmber 2017).

Dahniar, A.R. Pengaruh Asap Obat Nyamuk Terhadap Kesehatan dan Struktur 
VIVABIO

Jurnal Pengabdian Multidisiplin

Histologi Sistem Pernapasan. Jurnal kedokteran syiah Kuala 11(1) : 52-59

Fajarini, D.A. dan M. Murrukmihadi. 2015. Uji Aktivitas Repelan Minyak Atsiri Daun Kemangi (Ocimum basilicum L.) f. Citratum Back) Terhadap Nyamu Aedes aegypti Dalam Sediaaan Lotion dan Uji Sifat Fisik Lotion. Trad. Med.J. 20(2) : 91-97.

Faulde M.K. and O. Nehring. Synergistic Insecticidal and Repellent Effects of Combined Pyrethroid and Repellent Impregnated Bed Nets Using a Novel Long-lasting Polymercoating Multilayer Technique, Parasitol Res 2012; 111(2):755-765.

Fei, B. and J.H.N. Xin. 2007. N-diethyl-mToluamide-Containing Microcapsules for Bio-Cloth Finishing. Am J Trop Med Hyg. 77:52-57.

Harahap, P.S. 2014. Efektifitas Ekstrak Umbi Gadung (Dioscorea hipsida Dents.) dalam Pengendalian Larva Nyamuk. Jurnal IPTEKS Terapan 8(1).

Ikhsanudin, A. dan A.N. Azizah. 2017. Uji Aktifitas Repelan Terhadap Nyamuk Aedes aegypti Betina Sediaan Emulgel Minyak Atsiri Biji Pala (Myristica fragrans Houtt.). JF FIK UINAM 5(4) : 225-232.

Kementrian Kesehatan Republik Indonesia.

Profil Kesehatan Indonesia

2015.hlm.187-90.

Kusumastuti, N.H. 2014. Penggunaan Insektisida Rumah Tangga Antinyamuk Di Desa Pengandaran, Kabupaten Pangandaran. Widyariset 17(3) : 417424.
Liem, A.F; E. Holle; I.Y. Gemnafle and S. Wakun. 2013. Isolasi Senyawa Saponin dari Mangrove Tanjang (Bruguirera gymnorrhiza) dan Pemanfaatannya sebagai Pestsida Nabati pada Larva Nyamuk. Jurnal Biologi papua 5(1) : 2936

Mazid, M., T. A. Khan and F. Mohammad. 2011. Role of Secondary Metabolities in Defense Mechanisms of Plants. Biology and Medicine. Vol.3 (2) : 232-249.

Meda, A., C. E. Lamien, M. Romito, J. Milliogo and O. G. Nacoulina. 2005 Determination of Total Phenolic, Flavonoid and Proline Contents in Burkina Fasan Honey, as well as their Radical Scavenging Activity. Food Chemistry Vol. 91 (3) : 571-577.

Mendki, M.J.; A. P. Singh; S. N. Tikar; B.D. Parashar; V. Veer; S. V. Shukla and S. Prakash. 2015. Repellent activity of $N$, $\mathrm{N}$-diethylphenylacetamide (DEPA) with Essential Oils Against Aedes aegypti, Vector of Dengue and Chikungunya International Journal of Mosquito Research 2(3): 17-20

Mierziak, J., K. Kostyn and A. Kulma. 2014. Flavonoids as Important Molecules of Plant Interactions With the Environment. Molecules Journal. Vol. 19 : 16240-16265.

Millati, F.F. dan F.F. Sofian. 2018. Review Artikel : Kandungan Senyawa Minyak Atsiri Pada Tanaman Pengusir Nyamuk. Farmaka. 16(2) : 572-580.

Panneerselvam, C., K. Murugan. 2013. Adulticidal, Repellent, and Ovicidal Properties of Indigenous Plant Extracts Against the Malarial Vector, Anopheles 
Jurnal Pengabdian Multidisiplin

stephensi (diptera : Culicidae).

Parasitologi Research 112 : 679 -692.

Rahmatullah, W. 2018. Promodi Budidaya Tanaman Pengusir Nyamuk (Mosquito Repellent) pada PKK RT 31 RW 07 Dolahan Kelurahan Purbayan Kotagede. Jurnal ADIMAS, 24-29

Raju K.S. ; V.L.M. Raman and N. Sridevi. 2015. Study of Safety of Mosquito Repellents, J Den Med Sci. 14(1):42-45.

Raja A.S.M. ; S. Kawlekar; S. Saxena; A. Arputharaj; P.G. Patil. 2015. Mosquito Protective textiles - A review International Journal of Mosquito Research 2015; 2(4): 49-53

Saleh, M.; A. Susilawaty; Syarfaini dan Musdalifah. 2017. Uji Efektifitas Ekstrak Kulit Buah Jeruk nipis (Citrus aurantifolia) Sebagai Insektisida Hayati terhadap Nyamuk Aedes aegypti. Higiene 3(1) : 30-36

Sarker, S. D. and L. Nahar. 2007. Kimia. Bahan Organik, Alam dan Umum. Terj. A. Rohman. Pustaka Pelajar Yogyakarta. 542 hal. 